\section{Toxicological and}

Environmental

Chemistry

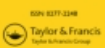

\section{Toxicological \& Environmental Chemistry}

ISSN: 0277-2248 (Print) 1029-0486 (Online) Journal homepage: https://www.tandfonline.com/loi/gtec20

\title{
Differential blood counting in fish as a non- destructive biomarker of water contamination exposure
}

Sandra Aparecida da Silva Corrêa, Denis Moledo de Souza Abessa, Luciana Gomes dos Santos, Edison Bezerra da Silva \& Robson Seriani

To cite this article: Sandra Aparecida da Silva Corrêa, Denis Moledo de Souza Abessa, Luciana Gomes dos Santos, Edison Bezerra da Silva \& Robson Seriani (2017) Differential blood counting in fish as a non-destructive biomarker of water contamination exposure, Toxicological \& Environmental Chemistry, 99:3, 482-491, DOI: 10.1080/02772248.2016.1189554

To link to this article: https://doi.org/10.1080/02772248.2016.1189554

里 Published online: 14 Jul 2016.

Submit your article to this journal $₫$

山 Article views: 121

View Crossmark data ¿

Citing articles: 2 View citing articles $\longleftarrow$ 


\title{
Differential blood counting in fish as a non-destructive biomarker of water contamination exposure
}

\author{
Sandra Aparecida da Silva Corrêa ${ }^{a}$, Denis Moledo de Souza Abessa ${ }^{b}$, \\ Luciana Gomes dos Santos ${ }^{c}$, Edison Bezerra da Silva ${ }^{a, d}$ and Robson Seriani ${ }^{a, b, c, e}$ \\ aPós Graduação em Ecogestão, Universidade Paulista - UNIP - Campus Paraíso/Vergueiro, São Paulo, Brazil; \\ bUniversidade Estadual Paulista - UNESP - Campus do litoral Paulista - Núcleo de Estudos em Poluição e \\ Ecotoxicologia Aquática, São Vicente, Brazil; 'Pós Graduação em Educação Ambiental, Universidade de \\ Guarulhos, UnG, Guarulhos, Brazil; ' EMEF Olavo Fontoura, Prefeitura do Município de São Paulo, São Paulo,

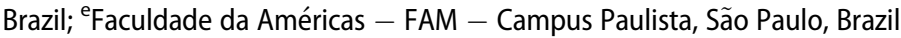

\begin{abstract}
Differential white blood cell counting was performed on blood from the fish species Oreochromis niloticus and was used as an in situ indicator of the species' exposure to contamination. Ten young fish were collected in an area influenced by the discharge of effluents and from a fish farm (control group). The fish were anesthetized and caudal puncture was used to collect the blood. Differential white blood cell counting was performed, as well as the counting of total leukocytes and thrombocytes (in 2000 cells). Physicochemical parameters of the water from both sites were analyzed. The water from the polluted area was found to have high conductivity and low levels of dissolved oxygen, factors that indicate poor environmental quality. Fish collected from the polluted site presented higher percentages of eosinophils and monocytes and fewer thrombocytes because of exposure to pollution and hypoxic conditions. The differential white blood cell count represents a suitable biomarker of environmental health and provides a tool for biomonitoring water quality.
\end{abstract}

\section{ARTICLE HISTORY}

Received 2 December 2015 Accepted 8 May 2016

\section{KEYWORDS}

Fish; hematology; aquatic pollution; biomonitoring; sewage; Oreochromis niloticus

\section{Introduction}

The characteristics of fish blood have long been used for assessing the physiological status of fish exposed to environmental stressors (França et al. 2007; Prado et al. 2014). Because blood flows continuously through the body and perfuses all organs and tissues, it integrates several levels of biological organization (physiology, histology, cytology, and hormonal regulation); thus, hematology may provide reliable information on the health status of a specimen.

The differential counting of blood cells is considered a suitable tool for assessing the health status of fish, and this approach has been employed in fish farms after drug administration and parasite infestations, as well as for other purposes (Ranzani-Paiva et al. 2008; Dias et al. 2011; Seriani, Abessa, et al. 2015; Ventura, Corsini, and de Araújo Gabriel 
2015). However, despite its potential to serve as a biomarker of exposure to natural or anthropic environmental stressors, the use of differential blood counting in biomonitoring as non-destructive biomarker has been limited. This limit is reflected in the lack of studies on most fish species. Thus, studies that evaluate the effects of both single contaminants and complex mixtures on the blood of fish are required in order to provide knowledge about how this biomarker responds to different types and levels of contaminants.

Urban effluents consist of complex mixtures containing many toxic compounds, such as organic substances, pharmaceuticals and personal care products, metals, hydrocarbons, detergents, pesticides, drugs, and other toxic contaminants (Seriani et al. 2010; Sibanda, Selvarajan, and Tekere 2015; Pereira et al. 2016). However, urban effluents are frequently disposed into the aquatic ecosystems without prior treatment, a process that has biological effects and threatens aquatic organisms and human health alike (Alimba, Saliu, and Ubani-Rex 2015).

Hematological changes have been considered good indicators of the health of fish, and are strongly related to the way fish respond to the environmental variations; thus they constitute an ideal tool for in vitro or in situ toxicological studies (Al-Akel and Shamsi 2000; Cicero, Barrella, and Rotundo 2014; Hamidipoor et al. 2015; Seriani, Franca, et al. 2015). Hematological changes also indicate physiological adjustments, because of changes in respiratory activity associated with $\mathrm{pH}$ of water, temperature, salinity, dissolved oxygen, respiratory metabolism, age, sex, body length, weight, and seasonal variations.

Leukocyte counting provides information about fish health, and the reduction in the number of lymphocytes is generally considered a stress response (Chen et al. 2002). Moreover, changes in the total number of leukocytes and thrombocytes were reported by Lemly (2002) in fish from contaminated environments. Thus, fish blood represents a good non-destructive biomarker for the assessment of pollutants in water.

Therefore, this study sought to determine if fish from a water body that receives urban effluents would exhibit alterations in their blood. A secondary goal was to identify changes in the differential white blood cell (WBC) counts, in order to observe if these variables would serve as a biomarker of exposure in fish.

\section{Methods}

\subsection{Study area}

The city of Barra Bonita is located in the mid-western region of São Paulo State, and is marked by the presence of the Tietê river and the Barra Bonita reservoir. The Tietê river is quite long (approximately 1,110 kilometers) and crosses almost the entire state, from the São Paulo Metropolitan Region to the Paraná river. The river is economically important to the state, largely because of the presence of a set of reservoirs and hydroelectric plants, and because in some regions, it is used for commercial navigation. In the Barra Bonita region, the river water presents high concentrations of organic matter, in terms of biochemical oxygen demand (BOD: $2.7-4.7 \mathrm{mg} / \mathrm{L}$ ), nitrite $(0.08-1.17 \mathrm{mg} \mathrm{N} / \mathrm{L})$, nitrate $(0.2-0.8 \mathrm{mg} \mathrm{N} / \mathrm{L})$, ammonia $(1.8-2.7 \mathrm{mg} \mathrm{N} / \mathrm{L})$, and phosphate $(0.08-0.21 \mathrm{mg} \mathrm{P} / \mathrm{L})$. Its transparency is low because of the presence of urban effluents and runoff from agricultural activities, especially those of sugarcane (Prado, Novo, and Pereira 2007; Buzelli and Cunha-Santino 2013). High concentrations of phenols (13 $\mu \mathrm{g} / \mathrm{L})$ and metals, 
such as mercury $(0.3 \mu \mathrm{g} / \mathrm{L})$, cadmium $(0.4 \mu \mathrm{g} / \mathrm{L})$, and as well as low levels of dissolved oxygen $(3.7 \mathrm{mg} / \mathrm{L})$, have been previously reported for this region and were found to be involved in the frequent occurrence of fish mortalities, mutagenicity, and genotoxicity (Rocha et al. 2009; Araújo, Guimarães, and Seriani 2014).

Along the surroundings of the sampling site, the land use is dominated by sugarcane plantations and urbanized areas contribute to aquatic pollution as metals, bacteria and organic compounds (Gouvêa, Vieira, and Lombardi 2005; Silvério et al. 2005; Rocha et al. 2010; Bramorski and Vilella 2015). According to State of São Paulo Environmental Agency (CETESB), the water quality in the Barra Bonita reservoir has degraded in the last few years, and the concentrations of arsenic (As), lead $(\mathrm{Pb})$, copper $(\mathrm{Cu})$, chromium $(\mathrm{Cr})$, dioxins, and furans in sediments exceeded the respective Canadian threshold effect levels, while concentrations of nickel (Ni) were above the probable effect level (CETESB 2014).

\subsection{Water quality}

Surface water samples were taken directly from the field through the use of glass flasks, and the following variables were measured following American Public Health Association (APHA 2005) protocols: dissolved oxygen levels $(\mathrm{mg} / \mathrm{L})$, temperature $\left({ }^{\circ} \mathrm{C}\right)$, suspended solids $(\mathrm{mg} / \mathrm{L}), \mathrm{pH}$, and conductivity $(\mu \mathrm{S} / \mathrm{cm})$.

\subsection{Test organisms}

Ten specimens of Oreochromis niloticus were collected at each study site as follows: 10 fish (mean weight $=33.2 \pm 4.0$ g; mean length $=13.0 \pm 0.7 \mathrm{~cm}$ ) were collected from a site close to the downtown area of the city of Barra Bonita $\left(22^{\circ} 29^{\prime} 59.39^{\prime \prime} \mathrm{S}-48^{\circ} 33^{\prime} 52.30^{\prime \prime} \mathrm{W}\right)$, while those used in the control group were collected from a fish farm located in the city of Pariquera-Açu, São Paulo State, Brazil $(n=10$; mean weight $=30.2 \pm 2.0 \mathrm{~g}$ and mean length $=10.0 \pm 0.5 \mathrm{~cm})$.

\subsection{Hematological analyses}

The fish from both Barra Bonita (polluted site) and fish farm (control) were placed in tanks containing water from the respective collection sites and acclimatized for 60 minutes to minimize the stress due to collection. All the collected fish from both study sites were anesthetized with clove oil according to protocol established for O. niloticus by Delbon and Ranzani-Paiva (2012). Next, blood was withdrawn using caudal puncture, which was performed using heparin-treated syringes. Immediately after sampling, blood smears were prepared on glass slides (in a number of slides per fish), fixed in methanol, and colored with May-Grünwald-Giemsa dye. Two thousand cells were analyzed per slide/animal under a compound optical microscope $(1000 \times)$ (Zeiss, Germany), and leukocytes and thrombocytes were identified and counted. Additional blood smears were used for differential (percent) counting of WBC (neutrophils, monocytes, lymphocytes, basophils, and eosinophils). 


\subsection{Statistical analyses}

First, the assumptions of normal distribution in each group and homogeneity of variances among groups were evaluated by using the Shapiro-Wilk test and Levene's test. As the data passed in the normality and homoscedasticity tests the two-tailed Student's $t$-test was applied to statistically compare each hematological variable between the two groups of fish, by using SigmaPlot ${ }^{\circledast}$ software. Variables were reported as means \pm standard deviations and the level of significance was set to $5 \%$.

\section{Results}

In the water from Barra Bonita, temperature $\left(21.1^{\circ} \mathrm{C}\right), \mathrm{pH}(8.1)$, and levels of suspended solids $(0.8 \mathrm{mg} / \mathrm{L})$ (Table 1$)$ were found to be in accordance with Brazilian guidelines/ National Environment Council of Brazil (CONAMA 2005) for Class 2 waters; however, conductivity $(127 \mu \mathrm{S} / \mathrm{cm})$ and dissolved oxygen levels $(1.0 \mathrm{mg} / \mathrm{L})$ were inconsistent with Brazilian guidelines, reflecting the release of wastewater at the location (CETESB 2010). The physicochemical conditions of the water from the fish farm (control) were in accordance with all Brazilian guidelines, and the water quality was found to be adequate for aquaculture.

The values of differential WBC counting and total leukocytes and thrombocytes are displayed in Table 2. Fish collected in Barra Bonita showed significantly higher

Table 1. Physical-chemical parameters of the water samples collected at the polluted site (Barra Bonita) and from the control area (commercial fish farm), and guidelines established for Class 2 waters by the Brazilian government (CONAMA 357/05).

\begin{tabular}{lccc}
\hline Variable & Polluted site Mean/SD & Control Mean/SD & CONAMA 357/05 \\
\hline $\mathrm{pH}$ & $8.1 \pm 0.2$ & $7.2 \pm 0.3$ & $6-9$ \\
Conductivity $(\mu \mathrm{S} / \mathrm{cm})$ & $127 \pm 1.2$ & $87 \pm 1.5$ & 100 \\
Dissolved oxygen $(\mathrm{mg} / \mathrm{L})$ & $1.0 \pm 0.9$ & $8.0 \pm 1.1$ & $\geq 6$ \\
Temperature $\left({ }^{\circ} \mathrm{C}\right)$ & $21.1 \pm 0.8$ & $21.0 \pm 2.1$ & - \\
Suspended solids $(\mathrm{mg} / \mathrm{L})$ & $0.8 \pm 0.1$ & $0.2 \pm 0.1$ & 500 \\
\hline
\end{tabular}

Table 2. Differential WBC counting of Oreochromis niloticus collected in Barra Bonita and a fish farm (control group), and values already found in healthy fish (mean and the respective standard deviations). Bold values and asterisks indicate significant differences between the control and exposed group $(p<0.05)$.

\begin{tabular}{|c|c|c|c|}
\hline \multirow[b]{2}{*}{$\begin{array}{l}\text { Cell types: percent } \\
\text { and variance }\end{array}$} & \multicolumn{2}{|c|}{ Samples } & \multirow[b]{2}{*}{$\begin{array}{l}\text { Number of cells in healthy fish, } \\
\text { according to Tavares-Dias and Moraes (2004) }\end{array}$} \\
\hline & $\begin{array}{l}\text { Control } \\
(n=10)\end{array}$ & $\begin{array}{l}\text { Polluted site } \\
\quad(n=10)\end{array}$ & \\
\hline \multirow[t]{2}{*}{ Lymphocytes } & $91.8 \pm 12(\%)$ & $84.6 \pm 9(\%)$ & \\
\hline & $70.2-90.1$ & $70.4-95.3$ & $30.9-86.5$ \\
\hline \multirow[t]{2}{*}{ Monocytes } & $2.7 \pm 4.8(\%)$ & $7.8 \pm 5.1^{*}(\%)$ & \\
\hline & $1.1-2.4$ & $2.1-8.1$ & $1.3-6.3$ \\
\hline \multirow[t]{2}{*}{ Neutrophils } & $3 \pm 3.8(\%)$ & $5.2 \pm 3.9(\%)$ & \\
\hline & $2-3$ & $4.5-6.0$ & $5.6-63.8$ \\
\hline \multirow{2}{*}{ Basophils } & $1.2 \pm 2.0(\%)$ & $0.2 \pm 1.0(\%)$ & \\
\hline & $0.1-0.9$ & $0.1-1.0$ & $0.0-1.7$ \\
\hline \multirow[t]{2}{*}{ Eosinophils } & $0.2 \pm 0.4(\%)$ & $1.2 \pm 0.7^{*}(\%)$ & \\
\hline & $0.1-0.4$ & $1.1-1.9$ & $0.0-1.7$ \\
\hline Total leukocytes / 2000 cells & $11.1 \pm 7.5$ & $12.6 \pm 8.8$ & Not available \\
\hline Thrombocytes / 2000 cells & $32.3 \pm 5.2$ & $20.6 \pm 4.8^{*}$ & Not available \\
\hline
\end{tabular}

*Indicate significant differences $(p<0.05)$ between the control and exposed group. 

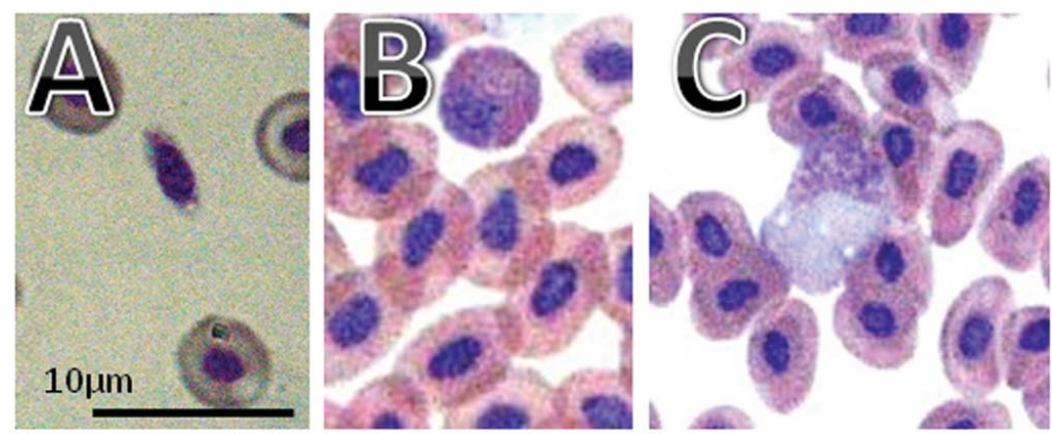

Figure 1. Peripheral blood cells from Oreochromis niloticus. (A) Thrombocytes, (B) eosinophil, and (C) monocyte. Stained with May-Grunwald-Giemsa.

percentages of monocytes $(p=0.03)$, eosinophils $(p=0.03)$, and fewer thrombocytes $(p=0.02)$ (Figure 1). In the case of total leukocytes and lymphocytes, neutrophils, and basophils, there were no differences between the Barra Bonita samples and the control.

\section{Discussion}

The Nile tilapia O. niloticus was selected for this study because it is considered an adequate biological model for a wide range of studies (Stickney 2000; Authman 2008; Guyon et al. 2012; Hauser-Davis et al. 2014). Besides, it has economic importance, is extensively produced in captivity worldwide, and is abundant and consumed throughout the study area.

Water conductivity values were high in Barra Bonita $(127 \mu \mathrm{S} / \mathrm{cm})$. Conductivity may serve as an indicator of domestic and industrial sewage in aquatic ecosystems (CETESB 2009); concentrations above $100 \mu \mathrm{S} / \mathrm{cm}$ often indicate that the environment may be affected by human actions and may indicate corrosiveness of the water. Buzelli and Cunha-Santino (2013) found values greater than $0.100 \mathrm{mS} / \mathrm{cm}$ in the Barra Bonita reservoir in both dry and wet seasons, and assumed that the predominant economic activities conducted in the vicinities (cultivation of sugarcane) contributed to the supply of ions in the waters of the reservoir as a result of storm water runoff. The dissolved oxygen levels in Barra Bonita water $(1.0 \mathrm{mg} / \mathrm{L})$ were low and were below the minimum limit established for Class 2 waters (which is $6.0 \mathrm{mg} / \mathrm{L}$ ), according to resolution 357/05 of National Environment Council of Brazil (CONAMA 2005). The concentration of dissolved oxygen in water could be used to determine water quality, since it directly affects aquatic biodiversity. Moreover, according to Valente, Padilha, and Silva (1997), Silvério et al. (2005), Zanata et al. (2008), Rocha et al. (2010), and Tonietto et al. (2015), the water analysis revealed that Barra Bonita presents conditions that are unsuitable for aquatic life.

Fish collected in the region where effluent discharge is present in Barra Bonita presented a significantly higher number of eosinophils. Recent studies performed on mammals showed that eosinophils are pleiotropic multifunctional leukocytes involved in the initiation and propagation of diverse inflammatory responses, as well as modulators of innate and adaptive immunity (Rothenberg and Hogan 2006). In mammals, eosinophils constitute a distinct lineage of granulocytes that provide innate immunity and act as 
the primary sentinels against infections (Hogan et al. 2008), and may be associated with the hypersensitivity and injury of tissues (Garcia-Navarro and Pachaly 1994). In fish, these cells are distributed throughout the connective tissue, and their function is not yet entirely clear; however, they are known to be present in larger numbers during chronic inflammatory processes and in periods of organic defense (Balla et al. 2010). Thus, they may present a similar role in fish and in mammals. Saad, Ezzat, and Shabana (1973) observed an increase in the percentage of eosinophils in fish collected from polluted sites that were under influence of sewage. Because this cell type is rarely observed in blood of fish (Powell, Wright, and Burka 1990), the high number of eosinophils in fish from the polluted site was surprising and suggested that the increase in this type of cell may be associated with inflammatory processes due to either parasite infestation or chemical compounds present in effluents. Further studies must be conducted in an attempt to better understand the role of eosinophils in fish and their response to environmental stressors.

The number of monocytes was higher in fish collected in the polluted site (Barra Bonita) as well. Monocytosis is suggestive of inflammatory response in teleost fish (Clauss, Dove, and Arnold 2008), a finding which corroborated the results obtained in studies involving eosinophils. Monocytes are circulating blood cells (Lorenzi 1999) which are able to migrate to peripheral tissues and then become macrophages. Monocytes may be considered the most important blood cells of the immune system due to their ability to absorb foreign material and cellular debris in the inflammatory response and other degenerative processes (Clauss, Dove, and Arnold 2008). In this sense, the data suggest that the immune system of the fish collected in the polluted site is stimulated, possibly due to compounds present in the urban effluent.

Fish collected in the polluted site presented fewer thrombocytes than the control fish did. Thrombocytes are comparable to platelets of mammals and play an important role in blood clotting. The decrease in these cells in peripheral blood may suggest the migration to hemorrhagic foci, as observed by Mazon et al. (2002) in a study on Prochilodus scrofa. Thrombocytopenia can have devastating effects on the fish, not only because these cells are responsible for blood clotting, but also because they control fluid loss and skin lesions and may be involved in responses to inflammatory processes (Clauss, Dove, and Arnold 2008). Thrombocytes also act in humoral defense and may have a phagocytic function (Burrows, Fletcher, and Manning 2001).

The hematological responses of fish from the polluted site may be connected to the poor water quality; however, we highlight that further studies should be conducted in order to identify the chemicals in water, sediments, and fish soft tissues, which will make it possible to establish cause-effect relationships. The presence of contaminants may have a series of effects on the composition of the blood (Bacchetta, Cazenave, and Parma 2011). Similarly, hypoxia was reported to induce increased numbers of WBC in flowerhorn fish (Kupittayanant and Kinchareon 2011). In fact, hypoxia may promote a range of morphological, behavioral, metabolic, and physiologic alterations in fish. According to Smart (1981), salmonids require a minimum of 5-6 mg/L of dissolved oxygen, whereas catfish and tilapia require levels about $3 \mathrm{mg} / \mathrm{L}$. However, literature on the effects of hypoxia on WBC is scarce and inconclusive, since studies observed a decrease in WBC in codfish (Hamoutene et al. 2009) after hypoxia, whereas no significant alteration in leukocyte numbers was observed in catfish (Scott and Rogers 1981). This 
discrepancy shows the need of further studies on the effects of hypoxia on WBC and the effects of its combination with contaminants.

\section{Conclusions}

In summary, fish collected in an area polluted by urban effluents have altered blood parameters, such as increased percentages of eosinophils and monocytes and fewer thrombocytes. These changes were apparently due to the poor water conditions. Hematological parameters in general, and differential WBC counting in particular, were considered good biomarkers of exposure to environmental stressors.

\section{Acknowledgments}

The authors would like to thank Mr Aquiles for his help during fish sampling. The authors would also like to thank the lab technicians, Sonia A.S. Feliciano (UNIP) and Guilherme F. Cavalheiro, for their assistance in laboratorial procedures and Dr Antônio F.G. Leonardo (APTA/ Polo Regional Vale do Ribeira, Pariquera-Açu, SP) for providing the fish for the control group.

\section{Disclosure statement}

All authors declare that they have no competing interest.

\section{References}

Al-Akel, A., and S. Shamsi. 2000. "A Comparative Study of the Toxicity of Lead and its Impact on the Carbohydrate Metabolism and some Haematological Parameters of Cichlid Fish, Oreochromis niloticus and Catfish, Clarius gariepinus from Saudi Arabia”. Toxicological \& Environmental Chemistry 74 (1-2): 19-28.

Alimba, C.G., J.K. Saliu, and O.A. Ubani-Rex. 2015. "Cytogenotoxicity and Histopathological Assessment of Lekki Lagoon and Ogun River in Synodontis clarias (Linnaeus, 1758)". Toxicological \& Environmental Chemistry 97 (2): 221-234.

APHA (American Public Health Association). 2005. "AWWA American Water Works Association; WPCF-Water Pollution Control Federation." Standard Methods for the Examination of Water and Wastewater. 21st ed. Washington, DC.

Araújo, A.L.S., E.T. Guimarães, and R. Seriani. 2014. "Mutagenesis in Tradescantia pallida as a Biomarker of the Effects of Water Polluted with Urban Effluent." Holos Environment 14 (1): 97-102.

Authman, M.M.N. 2008. "Oreochromis niloticus as a Biomonitor of Heavy Metal Pollution with Emphasis on Potential Risk and Relation to some Biological Aspects." Global Veterenaria 2 (3): 104-109.

Bacchetta, C., J. Cazenave, and M.J. Parma. 2011. "Responses of Biochemical Markers in the Fish Prochilodus lineatus Exposed to a Commercial Formulation of Endosulfan.” Water, Air, \& Soil Pollution 216 (1-4): 39-49.

Balla, K.M., G. Lugo-Villarino, J.M. Spitsbergen, D.L. Stachura, Y. Hu, K. Bañuelos, O. Romo-Fewell, R.V. Aroian, and D. Traver. 2010. "Eosinophils in the Zebrafish: Prospective Isolation, Characterization, and Eosinophilia Induction by Helminth Determinants.” Blood 116 (19): 3944-3954.

Bramorski, J., and S.M. Vilella. 2015. "Presence and Abundance of Public Interest Bacteria in Sediments from the Upper Compartments of Barra Bonitas Reservoirs, São Paulo-Brazil (Tietê and Piracicaba Rivers)." Revista de Ciências Ambientais 8 (2): 61-70. 
Burrows, A.S., T.C. Fletcher, and M.J. Manning. 2001. "Haematology of Turbot, Psetta maxima (L.): Ultrastructural Cytochemical and Morphological Properties of Peripheral Blood Leucocytes." Journal of Applied Ichthyology 17 (2): 77-84.

Buzelli, G.M., and M.B. Cunha-Santino. 2013. “Análise e diagnóstico da qualidade da água e estado trófico do reservatório de Barra Bonita (SP).” Ambi-Agua 8 (1): 186-205.

CETESB (Companhia Ambiental do Estado de São Paulo). 2009. Qualidade das águas interiores no Estado De São Paulo. Significado ambiental e sanitário das variáveis de qualidade das águas e dos sedimentos e metodologias analíticas e de amostragem. Série Relatórios Apêndice A. http:// www.cetesb.sp.gov.br/

CETESB (Companhia de Tecnologia de Saneamento Ambiental). 2010. "Relatório da qualidade das águas superficiais no Estado de São Paulo”. p. 310. http://www.cetesb.sp.gov.br/

CETESB (Companhia Ambiental do Estado de São Paulo). 2014. "Relatório da qualidade das águas superficiais no Estado de São Paulo". p. 414. http://www.cetesb.sp.gov.br/

Chen, W.H., L.T. Sun, C.L. Tsai, Y.L. Song, and C.F. Chang. 2002. "Cold-stress Induced the Modulation of Catecholamines, Cortisol, Immunoglobulin M, and Leukocyte Phagocytosis in Tilapia." General and Comparative Endocrinology 126: 90-100.

Cicero, L.H., W. Barrella, and M. Rotundo. 2014. "Hematological Parameters of Fish: Procedures for Environmental Analysis." Unisanta BioScience 3 (5): 50-63.

Clauss, T.M., A.D.M. Dove, and J.E. Arnold. 2008. "Hematologic Disorder of Fish." Veterinary Clinics of North America: Exotic Animal Practice 11: 445-462.

CONAMA (Conselho Nacional do Meio Ambiente). 2005. Dispõe sobre a classificação dos corpos de água e diretrizes ambientais para o seu enquadramento, bem como estabelece as condições e padrões de lançamento de efluentes, e dá outras providências. http://www.mma.gov.br/port/con ama/legiabre.cfm?codlegi $=459$

Delbon, M.C.E., and M.J.T.R. Ranzani-Paiva. 2012. "Eugenol em juvenis de tilápia do Nilo: concentrações e administrações sucessivas." Boletim do Instituto de Pesca 38 (1): 43-52.

Dias, D.D.C., L. Tachibana, R. Seriani, A.A. Santos, M.J.T. Ranzani-Paiva, and E. Romagosa. 2011. "Macrophagic Migration Time in Matrinxã, Brycon amazonicus, through Inoculation of Yeast, Saccharomyces cerevisiae, Technique." Acta Amazonica 41 (3): 421-424.

França, J.K.G., M.J.T. Ranzani-Paiva, J.V. Lombardi, S. Carvalho, and R. Seriani. 2007. "Toxicidade crônica do cloreto de mercúrio associado ao selênio por meio do estudo hematológico em tilápia Oreochromis niloticus." Bioikos 21 (1): 11-19.

Garcia-Navarro, C.E.K, and J.R. Pachaly. 1994. Manual de Hematologia Veterinária [Veterinary hematology]. São Paulo: Livraria Varela.

Gouvêa, S.P., A.A.H. Vieira, and A.T. Lombardi. 2005. "Copper and Cadmium Complexation by High Molecular Weight Materials of Dominant Microalgae and of Water from a Eutrophic Reservoir." Chemosphere 60 (9): 1332-1339.

Guyon, R., M. Rakotomanga, N. Azzouzi, J.P. Coutanceau, C. Bonillo, H. D’Cotta, and M. Conte. 2012. "A High-Resolution Map of the Nile Tilapia Genome: A Resource for Studying Cichlids and Other Percomorphs." BMC Genomics 13 (1): 1-17.

Hamidipoor, F., H.R. Pourkhabbaz, M. Banaee, and S. Javanmardi. 2015. "Sub-lethal Toxic Effects of Deltamethrin on Blood Biochemical Parameters of Japanese Quail, Coturnix japonica." Toxicological \& Environmental Chemistry 97 (9): 1217-1225.

Hamoutene D., K. Burt, S. Samuelson, G. Mabrouk, A. Mansour, and K. Williams. 2009. "In vitro Effect of Acute Hypoxia on Blood Cell Metabolism and Respiratory Burst Response in Three Aquaculture Finfish Species, Cod (Gadus morhua), Atlantic Salmon (Salmo salar), and Steelhead Trout (Oncorhynchus mykiss)." Canadian Technical Report of Fisheries and Aquatic Sciences 2831: 10p.

Hauser-Davis, R.A., F.F. Bastos, B. Tuton, R.C. Rocha, T. Saint'Pierre, R.L Ziolli, and M.A. Arruda. 2014. "Bile and Liver Metallothionein Behavior in Copper-Exposed Fish." Journal of Trace Elements in Medicine and Biology 28 (1): 70-74.

Hogan, S.P., H. Rosenberg, R. Moqbel, S. Phipps, P.S. Foster, P. Lacy, A. Barry, and M.E. Rothenberg. 2008. "Eosinophils: Biological Properties and Role in Health and Disease." Clinical \& Experimental Allergy 38 (5): 709-750. 
Kupittayanant, P., and W. Kinchareon. 2011. "Hematological and Biochemical Responses of the Flowerhorn Fish to Hypoxia." Journal of Animal and Veterinary Advances 10 (20): 2631-2638.

Lemly, A.D. 2002. "Symptoms and Implications of Selenium Toxicity in Fish: The Belews Lake Case Example." Aquatic Toxicology 57: 39-49.

Lorenzi, T.F. 1999. Manual de hematologia propedêutica e clínica [Hematology manual - Clinic and Propedeutics]. São Paulo: MDSI.

Mazon, A.F., E.A.S. Monteiro, G.H.D. Pinheiro, and M.N. Fernandes. 2002. "Hematological and Physiological Changes Induced by Short-term Exposure to Copper in the Freshwater Fish Prochilodus scrofa." Brazilian Journal of Biology 62 (4A): 621-631.

Pereira, C.D.S., L.A. Maranho, F.S. Cortez, F.H. Pusceddu, A.R. Santos, D.A. Ribeiro, and L.L. Guimarães. 2016. "Occurrence of Pharmaceuticals and Cocaine in a Brazilian Coastal Zone." Science of the Total Environment 548: 148-154. doi: 10.1016/j.scitotenv.2016.01.051.

Powell, M.D., G.M. Wright, and J.F. Burka. 1990. "Eosinofilic Granule Cells in the Gills of Rainbow Trout, Oncorhynchus mykiss: Evidence of Migration?” Journal of Fish Biology 37 (3): 495-497.

Prado, L.R., C. Felix, D.M.S. Abessa, L.M. Buruaem, L. Abujamara, A.A. Kirschbaum, G.C.R. Turatti, M.J.T. Ranzani-Paiva, A.T. Correia, and R. Seriani. 2014. "Hematological Parameters and Nuclear Abnormalities in Peripheral Erythrocytes of Achirus lineatus (Pleuronectiformes: Achiridae)." Comparative Clinical Pathology 361: 1-7.

Prado, R.B., E.M.L.M. Novo, and M.N. Pereira. 2007. "Evaluation of Land Use and Land Cover Dynamics in the Hydrographic Contribution Basin of Barra Bonita Reservoir - SP." [Avaliação da dinâmica do uso e cobertura da terra na bacia hidrográfica de contribuição para o reservatório de Barra Bonita - SP.] Revista Brasileira de Cartografia 59 (2): 127-135.

Ranzani-Paiva, M.J.T., A.A. Santos, D.C. Dias, R. Seriani, and M.I. Egami. 2008. "Hematological and Phagocytic Response of the Fat Snook, Centropomus parallelus, Reared in Net Cages, Before and After Inoculation with Sacharomyces ceresivisiae." Bioikos 22 (1): 29-35.

Rocha, P.S., E. Azab, B. Schmidt, V. Storch, H. Hollert, and T. Braunbeck. 2010. "Changes in Toxicity and Ah Receptor Agonist Activity of Sediments from the Tietê River (Sao Paulo, Brazil) - A Mass Balance Approach Using In vitro Methods and Chemical Analysis." Ecotoxicology and Environmental Safety 73: 550-558.

Rocha, P.S., G.L. Luvizotto, T. Kosmehl, M. Böttcher, V. Storch, T. Braunbeck, and H. Hollert. 2009. "Sediment Genotoxicity in the Tietê River (São Paulo, Brazil): In vitro Comet Assay Versus In situ Micronucleus Assay Studies." Ecotoxicology and Environmental Safety 72 (7): $1842-1848$.

Rothenberg, M.E., and S.P. Hogan. 2006. "The Eosinophil.” Annual Review Immunology 4: $147-174$.

Saad, M.A.H., A. Ezzat, and A. Shabana. 1973. "Effect of Pollution on the Blood Characteristics of Tilapia zillii G.” Water Air Soil Pollution 2: 171-179.

Scott, A.L, and W.A. Rogers. 1981. "Haematological Effects of Prolonged Sublethal Hypoxia on Channel Catfish Ictalurus punctatus (Rafinesque)." Journal of Fish Biology 18 (5): 591-601.

Seriani, R., D.M.S. Abessa, L.B. Moreira, J.P. Cabrera, J.Q. Sanches, C.L. Silva, F.A. Amorim, et al. 2015. "In vitro Mucus Transportability, Cytogenotoxicity, and Hematological Changes as Non-destructive Physiological Biomarkers in Fish Chronically Exposed to Metals." Ecotoxicology and Environmental Safety 112: 162-168.

Seriani, R., J.G. França, J.V. Lombardi, J.M. Brito, and M.J.T. Ranzani-Paiva. 2015. "Hematological Changes and Cytogenotoxicity in the Tilapia Oreochromis niloticus Caused by Sub-chronic Exposures to Mercury and Selenium." Fish Physiology and Biochemistry 41 (1): 311-322.

Seriani, R., L.B. Moreira, D.M.D.S. Abessa, L.D. Abujamara, N.S. de Carvalho, L.A. Maranho, A.A. Kirschbaum, and M.J.T. Ranzani-Paiva. 2010. "Hematological Analysis of Micropogonias Furnieri, Desmarest, 1823, Scianidae, from Two Estuaries of Baixada Santista, São paulo Brazil.” Brazilian Journal of Oceanography 58 (SPE3): 87-92.

Sibanda, T., R. Selvarajan, and M. Tekere. 2015. "Urban Effluent Discharges as Causes of Public and Environmental Health Concerns in South Africa's Aquatic Milieu." Environmental Science and Pollution Research 22 (23): 18301-18317. 
Silvério, P.F., A.L. Fonseca, C.M.R. Botta-Paschoal, and A.A. Mozeto. 2005. "Release, Bioavailability and Toxicity of Metals in Lacustrine Sediments: A Case Study of Reservoirs and Lakes in Southeast Brazil.” Aquatic Ecosystem Health \& Management 8 (3): 313-322.

Smart, G.R. 1981. “Aspects of Water Quality Producing Stress in Intensive Fish Culture.” In Stress and Fish, edited by A.D. Pickering, 277-293. New York: Academic Press.

Stickney, R.R. 2000. “Tilapia Culture.” In Encyclopedia of Aquaculture, edited by R.R. Stickney, 934-941. New York, NY: John Wiley and Sons.

Tavares-Dias, M., and F.R. Moraes. 2004. Hematology of Teleosts Fish. 1 ed.: Villimpress, Ribeirão Preto. 144 pp (In Portuguese).

Tonietto, A.E., A.T. Lombardi, R.B. Choueri, and A.A.H. Vieira. 2015. "Chemical Behavior of Cu, Zn, $\mathrm{Cd}$, and $\mathrm{Pb}$ in a Eutrophic Reservoir: Speciation and Complexation Capacity." Environmental Science and Pollution Research 22 (20): 15920-15930.

Valente, J.P.S., P.M. Padilha, and A.M.M.D. Silva. 1997. "Contribuição da cidade de Botucatu-SP com nutrientes (fósforo e nitrogênio) na eutrofização da represa de Barra Bonita.” Eclética Química, 22: 31-48.

Ventura, A.S., F.E. Corsini, and A.M. de Araújo Gabriel. 2015. "Hematologia como biomarcador de contaminação ambiental em peixes." Nutritime 12 (6): 4500-4507.

Zanata, L.H., E.L.G. Espíndola, O. Rocha, and R.H.G. Pereira. 2008. "Morphological Abnormalities in Cladocera (Branchiopoda) in a Cascade of Reservoirs in the Middle and Lower Tietê River (São Paulo, Brazil)”. Brazilian Journal of Biology 68 (3): 681-682. 